\title{
Pathobiology of Avian avulavirus 1: special focus on waterfowl
}

\author{
Zaib Ur. Rehman ${ }^{1,2+}$, Chunchun Meng ${ }^{1,3,4+}$, Yingjie Sun ${ }^{1}$, Khalid M. Mahrose ${ }^{5}$, Sajid Umar ${ }^{2}$, Chan Ding ${ }^{1,3,4^{*}}$ (1) \\ and Muhammad Munir ${ }^{6}$
}

\begin{abstract}
Avian avulaviruses serotype 1 (abbreviated as APMV-1 for the historical name avian paramyxovirus 1) are capable of infecting a wide spectrum of avian species with variable clinical symptoms and outcomes. Ease of transmission has allowed the virus to spread worldwide with varying degrees of virulence depending upon the virus strain and host species. The emergence of new virulent genotypes from global epizootics, and the year-to-year genomic changes in low and high virulence APMV-1 imply that distinct genotypes of APMV-1 are simultaneously evolving at different geographic locations across the globe. This vast genomic diversity may be favoured by large variety of avian species susceptibility to APMV-1 infection, and by the availability of highly mobile wild birds. It has long been considered that waterfowls are not sensitive to APMV-1 and are unable to show any clinical signs, however, outbreaks from the 90's contradict these concepts. The APMV-1 isolates are increasingly reported from the waterfowl. Waterfowl have strong innate immune responses, which minimize the impact of virus infection, however, are unable to prevent the viral shedding. Numerous APMV-1 are carried by domestic waterfowl intermingling with terrestrial poultry. Therefore, commercial ducks and geese should be vaccinated against APMV-1 to minimize the virus shedding and for the prevention the transmission. Genetic diversity within APMV-1 demonstrates the need for continual monitoring of viral evolution and periodic updates of vaccine seed-strains to achieve efficient control and eradication of APMV-1 in waterfowls.
\end{abstract}

\section{Table of Contents}

1 Introduction

2 Susceptibility of waterfowls for APMV-1 infection

3 Pathogenicity and special immune responses of waterfowl

4. Clinical findings

5 Experimental infection studies of ducks and geese with APMV-1

6 Role of waterfowls in emergence of APMV-1

7 Recent advances and challenges for control of Newcastle disease

8 Conclusions

\footnotetext{
*Correspondence: shoveldeen@shvri.ac.cn

'Zaib Ur. Rehman and Chunchun Meng contributed equally to this work

1 Shanghai Veterinary Research Institute (SHVRI), Chinese Academy

of Agricultural Sciences (CAAS), Shanghai 200241, China

Full list of author information is available at the end of the article
}

Additional file

References

\section{Introduction}

Newcastle disease (ND) is one of the most devastating and commonly prevalent diseases in the poultry industry, around the world. Owing to immense economic losses, World Organization for Animal Health has categorized the disease as "notifiable" [1]. The disease outbreaks are enormous and the host spectrum is broad, thus making $\mathrm{ND}$ as one of the primary limiting factor in the development of the poultry industry, especially in the developing countries [2,3]. It is caused by the Avian avulavirus 1 (APMV-1), which belongs to the Avulavirus genus within Paramyxoviridae family. All APMV-1 strains can be classified into velogenic (highly virulent), mesogenic (intermediate virulent) and lentogenic (non-virulent) based on the intracerebral pathogenicity index (ICPI) in day old specific pathogen free (SPF) chickens $[4,5]$ or nature of three amino acids at the position 113-116 in the

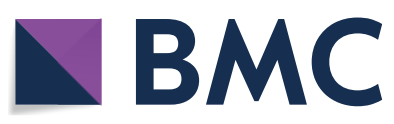

(c) The Author(s) 2018. This article is distributed under the terms of the Creative Commons Attribution 4.0 International License (http://creativecommons.org/licenses/by/4.0/), which permits unrestricted use, distribution, and reproduction in any medium, provided you give appropriate credit to the original author(s) and the source, provide a link to the Creative Commons license, and indicate if changes were made. The Creative Commons Public Domain Dedication waiver (http://creativecommons.org/ publicdomain/zero/1.0/) applies to the data made available in this article, unless otherwise stated. 
un-cleaved fusion protein cleavage site. APMV-1 is considered to be virulent, if these amino acids are basic in nature with a phenylalanine at position 117 , and having ICPI value of 0.7 in 1 day old chicks $[3,6]$.

APMV-1 is a single-stranded, negative-sense, non-segmented and enveloped RNA virus with genome length of $15.2 \mathrm{~kb}$. APMV-1 genome encodes for six co-linear genes that translate into six proteins and two non-structural proteins. Structural proteins include nucleoprotein (NP), matrix $(\mathrm{M})$, fusion $(\mathrm{F})$, hemagglutinin-neuraminidase $(\mathrm{HN})$, phosphoprotein $(\mathrm{P})$ and large RNA-dependent RNA-polymerase (L). The RNA editing of the P gene can result in the expression of $\mathrm{V}$ and $\mathrm{W}$ only in the virus infected cells [7-10]. Virulence of APMV-1 varies and depends upon the host species, and chicken and turkey are more susceptible than ducks and geese.

Generally, waterfowls were considered to be the natural reservoir for APMV-1 [1]; commonly for lentogenic APMV-1 [11]. Traditional view on the resistance of waterfowl against APMV-1 has been challenged since the report of continuous outbreaks in different provinces of china in goose (1997) $[12,13]$ and ducks (2002) [14]. Number of clinical ND outbreaks are increasing in the waterfowls [15-18]. Outbreaks of ND in ducks and geese indicate that these are not only the carrier, but also show clinical outcome of the disease. Factors that led to the change in the pathogenic spectrum of APMV-1 in waterfowl remain elusive. Investigation of the molecular mechanisms of increased pathogenicity of APMV-1 in waterfowls would provide foundations in designing any control strategies for the disease, as well as to improve health and welfare standards of the waterfowl.

The purpose of this review is to analyze our current understanding on the host-spectrum, molecular pathobiology of APMV-1 in waterfowls, and host immune responses that may play crucial roles in the disease prevention and control.

\section{Susceptibility of waterfowls for APMV-1 infection}

The Class I APMV-1 isolate was reported in 2006, however, currently these isolates are frequently being reported. Recent epidemiological studies direct that class I APMV-1 are common in domestic waterfowl. All viruses belong to class I are avirulent except JS10A10 and 9a5b strains $[19,20]$ which were generated by experimental consecutive passages through chicken. Amongst all genotypes of Class II, genotype I and II are the most prevalent genotypes in the waterfowl and have been isolated from many countries (summarized in Table 1). Waterfowl-origin isolates belonging to genotype VII of APMV-1 are constantly increasing especially in China, Republic of Korea, and Taiwan [16, 21-32]. These emerging outbreaks are increasing the global burden of APMV-1 and causes heavy economic losses [24]. Genotype IV and V have not been isolated from the waterfowl (Table 1). Collectively, these epidemiological studies clearly demonstrate the susceptibility of waterfowls for APMV-1 and their possible roles in the epizootiology of viruses.

Most of our understanding on the surveillance of APMV-1 in wild birds came from epidemiological studies on avian influenza viruses. Thus, it is required to design APMV-1 dedicated studies to effectively assess the true prevalence of the virus in wild birds. It is essential to understand and establish the foundations to devise control strategies, especially in wild-birds populated and highly vulnerable commercial poultry areas.

\section{Pathogenicity and special immune responses of waterfowl}

Waterfowls are less susceptible to APMV-1 compared to chickens, such as ducks and geese. A key reason for less susceptibility of waterfowl to APMV-1 is the presence of retinoic acid-inducible gene I (RIG-I). RIG-I is absent in the chicken [33] whereas it is present in ducks and goose (Figure 1) [7, 34]. RIG-I and melanoma differentiationassociated gene 5 (MDA5) are the foremost part of retinoic acid inducible gene-like receptors (RLRs) (Figure 1), which senses the cytoplasmic RNA [35]. These sensors can detect the nucleic acids of negative sense RNA such as APMV-1 and influenza viruses [36, 37], resulting in the production of the IFN type I and III, cytokines, chemokines and expression of the antiviral genes [38]. There is a vital role of the RLRs in the recognition of the viruses and antiviral immune responses in macrophages, fibroblast, and dendritic cells $[39,40]$. The V protein of APMV-1 blocks the "downstream" signaling pathway by interacting with MDA5 resulting in blockage of strong antiviral response of IFN- $\beta$ in chicken, which provide the benefit to waterfowl via RIG-I pathway [41, 42]. Positive correlation exist between the resistance to APMV-1 infection and expression of the antiviral genes including RIG-I, IRF3, IRF7 and IFN- $\beta$ [43] which was further confirmed in a study demonstrating increased expression of RIG-I ultimately leading to decreased APMV-1 load in vitro as well as in vivo [34].

APMV-1 infection increases the expression of interleukin (IL) IL-1 $\beta$, tumor necrosis factor- $\alpha$-like factor and interferon (IFN)- $\beta$ in duck embryo fibroblast (DEF) cells. Distinct innate immune responses of the waterfowl against APMV-1 may reason the resistance of waterfowls to these infections [44]. A higher level of innate immune genes expression has been observed in chicken embryo fibroblast (CEF) compared to the DEF cells [44]. An experimental study reveals that APMV-1 
Table 1 Field surveillance of ducks and geese for Avian avulavirus 1

\begin{tabular}{|c|c|c|c|c|c|}
\hline Class & Genotype & Specie/host & Region & Year(s) of isolation & References \\
\hline I & 1 & Duck, Mallards Teal & $\begin{array}{l}\text { (Zhejiang, Jiangsu, Guangxi, } \\
\text { Guizhou, Fujian, Guangdong, } \\
\text { Hubei, Guangxi, Shandong, } \\
\text { Shanghai) China } \\
\text { Sweden } \\
\text { (Hyogo) Japan } \\
\text { USA } \\
\text { (Central and Southern) Finland }\end{array}$ & $\begin{array}{l}2002,2007,2008,2011,2013,2015 \\
2016\end{array}$ & {$[11,22,69,75-79]$} \\
\hline । & 2 & $\begin{array}{l}\text { Duck } \\
\text { Teal, Mallards }\end{array}$ & $\begin{array}{l}\text { (Florida, Kentucky, Maryland, North } \\
\text { Carolina, Pennsylvania, South Caro- } \\
\text { lina, Vermont and Virginia) USA } \\
\text { Central and Southern, Finland } \\
\text { (Jiangsu, Anhui, Zhejiang, Fujian, } \\
\text { Shanghai) China } \\
\text { (Chonbuk) Republic of Korea }\end{array}$ & $\begin{array}{l}2009 \\
2006,2010 \\
2002,2006,2007 \\
2007\end{array}$ & {$[54,77,80]$} \\
\hline । & 3 & Duck & $\begin{array}{l}\text { (Shandong, Jiangsu, Zhejiang, } \\
\text { Jiangxi, Guangdong, Shanghai,) } \\
\text { China }\end{array}$ & $\begin{array}{l}2004,2005,2008,2009,2010,2012 \\
2013\end{array}$ & {$[21,63,68,81,82]$} \\
\hline । & 4 & Duck & (Jiangsu) China & 2010 & [83] \\
\hline । & 5 & Duck & $\begin{array}{l}\text { (Florida, Kentucky, Maryland, North } \\
\text { Carolina, Pennsylvania, South Caro- } \\
\text { lina, Vermont and Virginia) USA }\end{array}$ & 2009 & {$[80]$} \\
\hline$\|$ & 1 & $\begin{array}{l}\text { Duck } \\
\text { Teal, Mallard }\end{array}$ & $\begin{array}{l}\text { (Shandong, Henan, Jiangsu, Anhui, } \\
\text { Zhejiang, Anhui, Gaoming, Guang- } \\
\text { zhou, Guangdong) China } \\
\text { (Gyeongbuk, Chonnam, Chungbuk, } \\
\text { Chonbuk, Cheju) Republic of } \\
\text { Korea } \\
\text { (Republic of Sakha) Russia } \\
\text { (Island of Öland i.e. Southern part) } \\
\text { Sweden } \\
\text { Luxembourg } \\
\text { Yobe State, Nigeria } \\
\text { (Central and Southern) Finland } \\
\text { (Tohoku) Japan } \\
\text { (Northern Queensland) Australia } \\
\text { (South Dakota, Minnesota) USA } \\
\text { Taiwan }\end{array}$ & $\begin{array}{l}1995,2004,2005,2006,2007,2008 \\
2009,2010,2011\end{array}$ & {$[21,22,32,54,77,82,84-96]$} \\
\hline & & Pintail & Tohoku, Japan & 2003 & {$[97]$} \\
\hline$\|$ & $\|$ & Duck & $\begin{array}{l}\text { (Anhui, Yunfu) China } \\
\text { Luxembourg } \\
\text { Republic of Korea } \\
\text { (Tohoku) Japan } \\
\text { (North Dakota, South Dakota, Min- } \\
\text { nesota) USA } \\
\text { (Baluchistan, Sindh, Punjab) Pakistan }\end{array}$ & $\begin{array}{c}\text { 2005, 2005-2013, 2006-2008, } \\
\text { 2006-2009, 2008, 2014-2016 }\end{array}$ & {$[22,30,87,91,93,95,98]$} \\
\hline ॥ & $\mathrm{VI}$ & Duck/mallards & Finland & 2006 & [96] \\
\hline ॥ & VII & $\begin{array}{l}\text { Duck } \\
\text { Mallards } \\
\text { Black swan, Goose }\end{array}$ & $\begin{array}{l}\text { (Guizhou, Jiangsu, Beijing, Anhui, } \\
\text { Guangdong, Yunfu) China } \\
\text { (Adygea) Russia } \\
\text { Serbia } \\
\text { (Gyeongnam) Republic of Korea } \\
\text { Taiwan } \\
\text { (Punjab, Khyber Pakhtun Khwa) } \\
\text { Pakistan }\end{array}$ & $\begin{array}{l}2000,2005,2006,2007,2008,2009 \\
\quad 2010,2014,2015,2016\end{array}$ & {$[16,21-32,98-101]$} \\
\hline$\|$ & IX & Duck & $\begin{array}{l}\text { (Jiangsu, Beijing, Shandong, South- } \\
\text { ern China, Guangxi) China }\end{array}$ & 2009, 2010, 2011 & {$[16,24,28,31,102]$} \\
\hline ॥ & $X \mathrm{XIII}$ & Duck & Yobe State, Nigeria & 2008 & {$[88]$} \\
\hline । & 1 & Geese & $\begin{array}{l}\text { (Alaska) Japan } \\
\text { USA }\end{array}$ & 1991, 2007 & {$[11,103]$} \\
\hline । & 3 & Geese & $\begin{array}{l}\text { (Jiangsu, Shanghai, Shandong) } \\
\text { China }\end{array}$ & 2008, 2009, 2011, 2012 & {$[63]$} \\
\hline
\end{tabular}


Table 1 (continued)

\begin{tabular}{llllll}
\hline Class & Genotype & Specie/host & Region & Year(s) of isolation & References \\
\hline$\|$ & I & Geese & Yobe State, Nigeria & 2008 & {$[88]$} \\
$\|$ & $\|$ & Geese & (Jiangsu) China & 2003,2006 & {$[104,105]$} \\
$\|$ & \|\| & Geese & (Jiangsu, Guangxi) China & 2005,2006 & {$[106]$} \\
$\|$ & VI & Geese & (Jiangsu, Guangdong) China & 1998,2013 & {$[18,107]$} \\
$\|$ & VII & Geese & (Jiangsu, Guangxi, Anhui, Jilin, & $1997-2001,2003-2008$ & {$[18,27,30,31,104-106,108,109]$} \\
$\|$ & IX & Geese & Shanghai) China & 1997 & {$[31]$} \\
$\|$ & XII & Geese & China & 2010,2011 & {$[110]$} \\
\hline
\end{tabular}

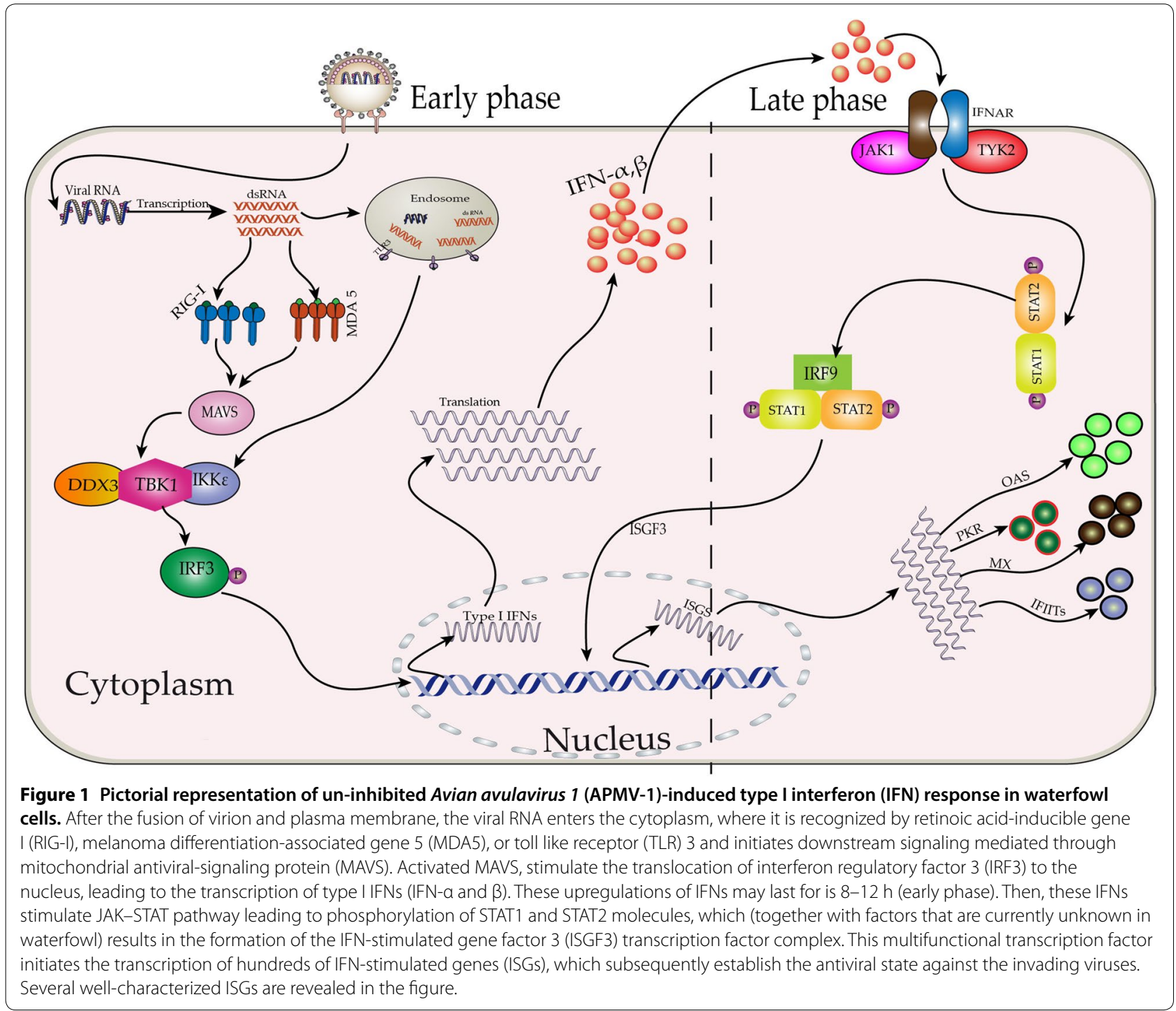

stimulate a strong and intense expression of the IFN- $\beta$ in ducks compared to chickens [42], and also up-regulate the IFN- $\beta$, IFN-regulatory factor 7 (IRF-7), and decreases the virus titer in goose lung and air-sac postinfection [34]. These observations dictate that the strong innate immune responses is a plausible reasons 
for less susceptibility of duck [42] and geese because its strong protective effects have been revealed to decrease the virus titer in goose-transfected cell [34], which may not be compensated by the IFN- $\alpha$ [33]. Recently, Yang et al. [45] have demonstrated that overexpression of $2^{\prime}-5^{\prime}$-oligoadenylate synthetase-like gene lessens the replication of APMV-1 in goose cells. In conclusion, waterfowls have diverse innate immunity components, which possibly increase their resistance to the APMV-1 [42].

\section{Clinical findings}

Besides the strong innate immune responses, waterfowl are generally considered long-term carrier of APMV-1 and disease outbreaks have been reported since 1997 [12-14], and were confirmed by follow up experimental studies. Clinically and naturally infected ducks and geese with APMV-1 show clinical signs such as elevated body temperature, excessively excreted oral mucus, dried cloaca, watery, greenish-white diarrhea, vain attempts of eating and drinking, listlessness, anorexia, crouch, eyelid edema and emaciation [14, 23, 46, 47]. Ducks may show up to $70 \%$ decrease in egg production, $80 \%$ morbidity and $67 \%$ mortality $[15,48]$ however the mortality in ducks varies with the different breeds, virus strain and dose of virus [15]. Some birds also show weakness of legs and wing along with unilateral or bilateral incomplete paralysis and the effects of this paralysis increases with progression of the disease [46]. Duck and geese also show the neurological signs such as muscular trembles, muscular dis-coordination, circling, and twisting of head and neck [23, 46, 48]. These clinical signs disappear according to infection status; mildly affected recover sooner and severely affected birds may recover after 15 days of infection [22, 46].

APMV-1 infected ducks and geese show the gross lesions on the immune organs such as bursa, spleen, thymus, mild to severe tracheitis, kidney enlargement, necrosis of pancreas, congestion on the meninx and in the brain and diffuse brain edema, focal hemorrhages in the mucosa of the proventriculus and intestine (especially duodenum and upper part of jejunum) [14, 22, $23,46]$. Bursal atrophy, hemorrhagic thymus and splenomegaly with white necrotic spots were found in the APMV-1 infected geese and duck [23, 46]. These lesions and histopathological changes may be due to higher viral loads, multi-systemic distribution of the virus in these immune organs [23]. As these immune organs are the reservoir of immune cells, and their destruction may lead to low antibody titer and other infections.

\section{Experimental infection studies of ducks and geese with APMV-1}

Experimental infection studies are necessary to determine the virulence and pathogenesis, in different bird types, age, species, intervention strategies, evaluation, comparison of vaccines etc. Different scientists propose diverse reasons for experimental infection studies and the design of the experimental infection studies varies greatly with the above-mentioned factors. Experimental infection studies on the pathogenesis, infection route, most susceptible age, bird line and immune responses are limited in waterfowl and available information is summarized in Additional file 1 and are briefly discussed below.

Kang et al. [44] have studied the immune related gene expression of chicken and duck embryonic fibroblast (CEF, DEF), by infecting them with APMV-1 of moderate virulent strain $\mathrm{NH}-10$ and highly virulent strain SS-10. Upregulated expression of the Toll like receptor (TLR) 3, TLR7, IL-1 $\beta$, IL-6, IFN- $\alpha$, IFN- $\gamma$, MHC-I and MHC-II were observed both in CEF and DEF, however, these expression levels were higher in CEF (mechanism is described briefly in Figure 1). Peking duck infection at 3 week of age with $\mathrm{NH}-10$ and SS-10 via intranasal route showed the systemic replication of the virus into small intestine, cecal tonsils, brain, lung, bursa of Fabricius, thymus, and spleen. This study also demonstrated the increased expression of the TLR3, TLR7, RIG-I, MDA5, IL-1 $\beta$, IL-2, IL-6, IL- 8 , IFN- $\alpha$, IFN- $\beta$, IFN- $\gamma$ in lungs compared to thymus. Furthermore, the higher expression level of TLR3, TLR7, IL-1 $\beta$, IL-2, IL-8, IFN- $\alpha$, IFN- $\gamma$ and MHC II were induced by NH-10 than SS-10 in the lungs. Whereas, the expression of the IL- 6 and IFN- $\beta$ in lung as well as thymus was higher for SS-10 group [7]. Similarly, a study of the Zhong et al. [49] has demonstrated the upregulation of the viperin (an IFN stimulated gene) in the DEFs and also in the spleen, kidneys, liver, brain, and blood of Changbai ducks infected with G7 APMV-1 through intranasal or intramuscular route. Experimental infection of geese with genotype VII APMV-1 upregulate the expression of TLR $1-3,5,7$, and 15, avian $\beta$-defensin $5-7,10,12$, and 16 , IL-8, IL-18, IL-1 $\beta$, and IFN- $\gamma$, and MHC class I in different tissues [50].

Intranasal inoculation of the Japanese commercial ducks and chicken males with artificially made APMV-1 class I virus $9 \mathrm{a} 5 \mathrm{~b}$ results in the higher IFN- $\beta$ in the duck compared to chicken. This study also demonstrated that replication, distribution, tissue damage and apoptosis were more in the immune organs of the chicken compared to duck [42]. Intramuscular infection of different ducks (mallard, Gaoyou, Shaoxing, Jinding, Shanma, and Peking ducks) with JSD0812 strain showed that different strains vary in the susceptibility to the disease [46]. Mallard are the most susceptible and Peking ducks are the 
most resistant species of birds. Infection of the Gaoyou duck at $15,30,45,60$, and 110 with different routes indicate that their susceptibility to disease and virus shedding decreases with the age and birds seldom die after infection through the natural route [46]. Experimental co-infection of ducks with APMV-1, and low or high pathogenic avian influenza virus (LPAIV and HPAIV) indicate that it decreases the virus shedding and transmission to the naïve ducks by contact [51]. Duck after immunization with inactivated vaccine of APMV-1, and challenge with the same live virulent Kenyan APMV-1 resulted in the development of more antibody titer than the unchallenged birds [52]. Experimental infection of geese with virulent APMV-1 genotype VIId and goose origin APMV-1 showed the extensive replication of geese in the immune organs which correlated with the clinical signs and lesions $[12,23]$ and also it transmission to SPF chickens [12]. Geese and chicken were vaccinated, then infected with goose-origin APMV-1/NA-1 and chickenorigin APMV-1/F48E9, and F48E8 viruses (Additional file 1). Geese are more resistant to F48E8 virus after vaccination. Results indicate that NA-1 vaccine provides a better protection in the form of less morbidity, less mortality and less virus shedding after challenge [53]. Although several natural outbreaks and experimental infections of APMV-1 in waterfowl had been reported. However, it remain to be clarified whether it cause the disease in waterfowl [46]. Inconsistent results in the infection of APMV-1 in waterfowl are due to APMV-1 strain, dose and rout of inoculation, breed, and maternal antibody titer (Additional file 1). Ducks are more resistant to infection through natural route than the geese [46].

In conclusion, these studies indicate that different viruses affect the immune organs and innate immune genes in diverse mechanisms. Waterfowls are more susceptible to APMV-1 infection at an early age, and through natural route results in less damage to immune organs. More comprehensive and detailed studies are warranted for the control of ND in waterfowl.

\section{Role of waterfowls in emergence of APMV-1}

Waterfowl are naturally infected with large number of the viruses which are avirulent and do not cause the diseases in domesticated poultry. Waterfowl are commonly considered to be the natural host as well as carrier of APMV-1 [4]. APMV-1 isolates from the waterfowl are generally lentogenic or potentially pathogenic [54], and may be transmitted to the avian species, leading to increase attention for their role in the transmission/spread and emergence of ND [55-57]. There are increasing concerns about the increased virulence from the lentogenic to mesogenic to virulent pathotypes upon cyclic replication in poultry. These lentogenic isolates may converted to pathogenic viruses through serial passage in susceptible birds $[19,20,58]$ and one such isolate have already been documented to be the causative agent of the outbreak in the Ireland [59], but disappeared quickly. All the Class I APMV-1's had been isolated from the waterfowl, indicating them the natural carrier of these viruses (Table 1). Live bird market (LBM) epidemiological study in United States indicated that from avirulent viruses, $70 \%$ belong to class I and 30\% belongs to Class II [60]. There is close phylogenetic relationship between the avirulent viruses isolated from the LBM and waterfowl, indicating that APMV-1's may be transmitted from the waterfowl to the domestic poultry $[60,61]$. Transmission of APMV-1 may occur through different routes like, ingestion of the contaminated feed, water air, contaminated feces, animals, humans, contaminated eggs etc. [62]. Mostly domestic waterfowl are reared in semi-closed areas, where they may have the contact with the wild birds and domestic poultry. Therefore, it provides the best natural environment for the spread of APMV-1's [20, 63].

Waterfowl and shorebirds are not only the host, but are also infected by the APMV-1 and these viruses can also cause the disease in domesticated poultry $[55,56,64]$. Many virulent isolates from the domestic poultry cannot cause disease in waterfowl $[21,53]$. Most prevalent virulent genotype VII causing the endemics in China, Japan, Korea $[18,60,65]$ are co circulating into the ducks and chicken [66]. This coevolution was further confirmed when the results of Huang et al. [67] declared that some of the circulating APMV-1 had the multiple homologous genomes from chicken, ducks and geese. So, there is dire need to modernize the housing system of waterfowl according to biosecurity point of view to prevent their contact with terrestrial poultry and wild birds. Otherwise, number of virulent [16, 21-29] and avirulent [21, $63,68,69]$ isolates from the waterfowl may easily transmit to commercial poultry farm.

APMV-1 infected waterfowls shed the virus for an extended period of time [24] whereas, the infected chickens clears themselves rapidly and shed virus for short duration [70]. This prolonged virus shedding may facilitate the transmission, persistence and evolved to get some point mutation in the virus [66]. Major issue that should be concerned for virologists is the high evolution rate of some Class I APMV-1 isolates from waterfowls. Pathogenicity of some Class I APMV-1 isolates are constantly increasing and they are naturally converted to low virulent from avirulent viruses (unpublished findings from our lab). This was confirmed by the results of the Meng et al. [20] and Shengqing et al. [19] in which they artificially develop the virulent viruses through serial 
passage in the air sac and brain of chicken, from avirulent viruses of waterfowl origin. Although the conditions provided in these studies are not naturally existing but recovery of the virus from the air sacs after challenged via nasal or ocular route indicate the possibility of this mechanism.

In conclusion waterfowl plays a vital role in the transmission and re-emergence of ND in terrestrial poultry. It is recommended that rearing facilities of the waterfowl should be separated from commercial poultry.

\section{Recent advances and challenges for control of Newcastle disease}

Cumulating evidences indicate that genetic resistance to APMV-1 exists in various breeds of waterfowl [15]. Comprehensive studies are needed to determine the genetic variability against APMV-1 in different breeds of waterfowls. Genetic resistance of more susceptible breeds can be improved by including the resistant birds in the breeding programs of the commercial waterfowl [6]. APMV-1 resistant breeds should be used to produce highly efficient transgenic poultry birds [6].

Although constant outbreaks of ND have been reported in waterfowl from China and other East Asian countries, however, vaccination against ND in waterfowl is still a matter of debate. There are two consortia of scientists; one favors the vaccination and, others think that domestic waterfowl should not be vaccinated. These veterinarians have their own views, scientist, in the favors of vaccination argue, that it will decrease the chances of outbreaks and lessons the virus shedding. But, scientists, which are against vaccination argue that it will increase the virus burden on the birds, consequently increase the variation rate. The annual rate of change of virulent viruses could be as high as ten times the rate of change of low virulence APMV-1, suggesting that other selective pressures such as vaccination may accelerate the rate of evolution of virulent viruses [71, 72]. They claim that the rearing conditions of waterfowl could not be changed in future because they require water for breeding. Therefore, it is not plausible to prevent their contact with wild birds, resulting in transfer of the wild bird viruses to domestic waterfowls. Secondly, they claim vaccine will develop the antibody titers that will interact with the virus in the future exposures. These antibody responses may force the viruses for evolution. Our viewpoint supports the group of scientists, which claims that birds should be vaccinated. Because, it had already been established that APMV-1 cause the disease in waterfowl $[7,46,49,52]$ and vaccination prevent the chances of the outbreak. Second most important reason is the prolonged virus shedding by non-vaccinated birds, which may transfer to other poultry species and cause heavy economic losses. Theory, that vaccination will increase the virus burden is not very interesting in case of waterfowl because, without vaccination we have to face the same consequences of the high evolution rate. Waterfowls are naturally infected with large and diverse groups of viruses [73]. Development of the vaccines for waterfowl may require strains of waterfowl origin [53] because some lentogenic vaccines phylogenetically are far away than the infectious virus thus may provide partial protection to waterfowl [74]. Vaccine should also be killed because live vaccine virus replicates in the body and leads to shedding of the virus. Virus shedding of live vaccine may interact with the other APMV-1's present in the environment or birds and results in recombination and future evolution.

\section{Conclusions}

Waterfowls are not only the carrier but also susceptible to APMV-1. Strong innate immune responses may attribute to the less susceptibility of ND to waterfowl. Viral shedding by waterfowl for prolonged duration may increase the transmission, evolution and emergence of new viral strains. A number of APMV-1 isolates from the waterfowl are reported with high mutation rate, which is an alarming matter and may cause the endemics in future. Pathogenicity of ND is affected by different factors such as type, dose, and inoculation route of the virus, and species and age of birds.

Further studies are needed to explore the mechanism, and its intervention to prevent the virus shedding by the waterfowl for a long period. Continuous studies are also required to monitor the APMV-1 in the waterfowl, which may be the future threat to commercial poultry industry. Studies on the humoral immune responses of waterfowl are crucial to develop better intervention strategies. It is recommended that rearing facilities of the waterfowl including ducks and geese should be separated from chicken and turkey flocks to prevent the virus transmission.

\section{Additional file}

Additional file 1. Experimental infection studies of ducks and geese with Avian Avulavirus 1. Table summarizes the pathobiological findings and immune responses of waterfowl after experimental challenge with Avian Avulavirus 1.

\section{Abbreviations}

APMV-1: Avian avulavirus 1; ND: Newcastle disease; ICPI: intracerebral pathogenicity index; SPF: specific pathogen free; NP: nucleoprotein; M: matrix; F: fusion; HN: hemagglutinin-neuraminidase; P: phosphoprotein; L: large RNA-dependent RNA-polymerase; RNA: ribonucleic acid; IFN: interferon; CEF: chicken embryo fibroblast; DEF: duck embryo fibroblast; TLR: toll like receptor; 
MAVS: mitochondrial antiviral-signaling protein; IRF: interferon regulatory factor; ISGs: interferon stimulated gene; ISGF: interferon stimulated gene factor; LPAIV: low pathogenic avian influenza virus; HPAIV: high pathogenic avian influenza virus.

\section{Competing interests}

The authors declare that they have no competing interests.

\section{Authors' contributions}

ZUR, CM and CD developed the idea; ZUR and CM collected the data, wrote and revised the manuscript; CM, YS, KMM and SU helped in collection of data and contributed to writing the manuscript; MM helped in the illustrations; MM and $C D$ critically revised the manuscript. All authors read and approved the final manuscript.

\section{Acknowledgements}

These authors are funded by National Key Research and Development Program of China (No. 2018YFD0500100), Shanghai Key Laboratory of Veterinary Biotechnology (No. klab201702) and National Natural Science Foundation of China (No. 31530074).

\section{Author details}

1 Shanghai Veterinary Research Institute (SHVRI), Chinese Academy of Agricultural Sciences (CAAS), Shanghai 200241, China. ${ }^{2}$ Department of Poultry Science, Faculty of Veterinary and Animal Sciences, PMAS Arid Agriculture University, Rawalpindi 46300, Pakistan. ${ }^{3}$ Jiangsu Co-innovation Center for Prevention and Control of Important Animal Infectious Diseases and Zoonoses, Yangzhou 225009, China. ${ }^{4}$ Shanghai Key Laboratory of Veterinary Biotechnology, Shanghai 200241, China. ${ }^{5}$ Poultry Department, Faculty of Agriculture, Zagazig University, Zagazig 44511, Egypt. ${ }^{6}$ Biomedical and Life Sciences, Lancaster University, Lancaster LA1 4YG, UK.

\section{Publisher's Note}

Springer Nature remains neutral with regard to jurisdictional claims in published maps and institutional affiliations.

\section{Received: 19 April 2018 Accepted: 27 August 2018} Published online: 19 September 2018

\section{References}

1. Dimitrov KM, Ramey AM, Qiu X, Bahl J, Afonso CL (2016) Temporal, geographic, and host distribution of avian paramyxovirus 1 (Newcastle disease virus). Infect Genet Evol 39:22-34

2. Dai Y, Liu M, Cheng X, Shen X, Wei Y, Zhou S, Yu S, Ding C (2013) Infectivity and pathogenicity of Newcastle disease virus strains of different avian origin and different virulence for mallard ducklings. Avian Dis $57: 8-14$

3. OIE (2012) OIE Terrestrial Manual 2012. Manual of diagnostic tests and vaccines for terrestrial animals. World Organisation for Animal Health, Paris, pp 576-586

4. Miller P, Koch G (2013) Newcastle disease. In: Swayne DE, Glisson JR, McDougald LR, Nolan LK, David LS, Nair VL (eds) Diseases of poultry, $13^{\text {th }}$ edn. Wiley, New York, pp 98-107

5. Qamar-un-Nisa Younus M, Muti-ur-Rehman Maqbool A, Umar S (2017) Pathological alterations during co-infection of Newcastle disease virus with Escherichia coli in broiler chicken. Pakistan J Zool 50:495-503

6. Kapczynski DR, Afonso CL, Miller PJ (2013) Immune responses of poultry to Newcastle disease virus. Dev Comp Immunol 41:447-453

7. Kang Y, Li Y, Yuan R, Feng M, Xiang B, Sun M, Li Y, Xie P, Tan Y, Ren T (2015) Host innate immune responses of ducks infected with Newcastle disease viruses of different pathogenicities. Front Microbiol 6:1283

8. Rehman ZU, Qiu X, Sun Y, Liao Y, Tan L, Song C, Yu S, Ding Z, Munir M, Nair V, Meng C, Ding C (2018) Vitamin E supplementation ameliorates Newcastle disease virus-induced oxidative stress and alleviates tissue damage in the brains of chickens. Viruses 10:E173

9. Akhtar S, Muneer MA, Muhammad K, Tipu MY, Anees M, Rashid I, Raza-ur-Rehman Hussain I (2017) Molecular characterization and epitope mapping of fusion (F) and hemagglutinin (HN) genes of avian paramyxovirus serotype i from peacocks in Pakistan. Pakistan J Zool 49:755-759

10. Rehman ZU, Che L, Ren S, Liao Y, Qiu X, Yu S, Sun Y, Tan L, Song C, Liu W, Ding Z, Munir M, Nair V, Meng C, Ding C (2018) Supplementation of vitamin e protects chickens from Newcastle disease virus-mediated exacerbation of intestinal oxidative stress and tissue damage. Cell Physiol Biochem 47:1655-1666

11. Ramey AM, Reeves AB, Ogawa H, Ip HS, Imai K, Bui VN, Yamaguchi E, Silko NY, Afonso CL (2013) Genetic diversity and mutation of avian paramyxovirus serotype 1 (Newcastle disease virus) in wild birds and evidence for intercontinental spread. Arch Virol 158:2495-2503

12. Wan $H$, Chen L, Wu L, Liu X (2004) Newcastle disease in geese: natural occurrence and experimental infection. Avian Pathol 33:216-221

13. Phan LV, Park MJ, Kye SJ, Kim JY, Lee HS, Choi KS (2013) Development and field application of a competitive enzyme-linked immunosorbent assay for detection of Newcastle disease virus antibodies in chickens and ducks. Poult Sci 92:2034-2043

14. Yu H, Li WY, Cheng LF, Shi SH, Peng CX, Fu GH (2005) Isolation and identification of paramyxovirus type 1 from duck. Chin J Prev Vet Med 2:015

15. Shi SH, Huang Y, Cui SJ, Cheng LF, Fu GH, Li X, Chen Z, Peng CX, Lin F, Lin JS, Su JL (2011) Genomic sequence of an avian paramyxovirus type 1 strain isolated from Muscovy duck (Cairina moschata) in China. Arch Virol 156:405-412

16. Zhang S, Wang X, Zhao C, Liu D, Hu Y, Zhao J, Zhang G (2011) Phylogenetic and pathotypical analysis of two virulent Newcastle disease viruses isolated from domestic ducks in China. PLoS One 6:e25000

17. Wen G, Wang M, Wang H, Li L, Luo Q, Zhang T, Cheng G, Shao H (2016) Genome sequence of a virulent genotype III Newcastle disease virus isolated from laying ducks in China. Genome Announc 4:e01436

18. Liu XF, Wan HQ, Ni XX, Wu YT, Liu WB (2003) Pathotypical and genotypical characterization of strains of Newcastle disease virus isolated from outbreaks in chicken and goose flocks in some regions of China during 1985-2001. Arch Virol 148:1387-1403

19. Shengqing $Y$, Kishida N, Ito H, Kida H, Otsuki K, Kawaoka Y, Ito T (2002) Generation of velogenic Newcastle disease viruses from a nonpathogenic waterfowl isolate by passaging in chickens. Virology 301:206-211

20. Meng C, Qiu X, Yu S, Li C, Sun Y, Chen Z, Liu K, Zhang X, Tan L, Song C, Liu G, Ding C (2016) Evolution of Newcastle disease virus quasispecies diversity and enhanced virulence after passage through chicken air sacs. J Virol 90:2052-2063

21. Kang Y, Xiang B, Yuan R, Zhao X, Feng M, Gao P, Li Y, Li Y, Ning Z, Ren $T$ (2016) Phylogenetic and pathotypic characterization of Newcastle disease viruses circulating in South China and transmission in different birds. Front Microbiol 7:119

22. Wu W, Liu H, Zhang T, Han Z, Jiang Y, Xu Q, Shao Y, Li H, Kong X, Chen $\mathrm{H}$, Liu S (2015) Molecular and antigenic characteristics of Newcastle disease virus isolates from domestic ducks in China. Infect Genet Evol 32:34-43

23. Lu A, Diao Y, Chen H, Wang J, Ge P, Sun X, Hao D (2014) Evaluation of histopathological changes, viral load and immune function of domestic geese infected with Newcastle disease virus. Avian Pathol 43:325-332

24. Kang Y, Li Y, Yuan R, Li X, Sun M, Wang Z, Feng M, Jiao P, Ren T (2014) Phylogenetic relationships and pathogenicity variation of two Newcastle disease viruses isolated from domestic ducks in southern China. Virol J 11:147

25. Liu M, Shen X, Cheng X, Li J, Dai Y (2015) Characterization and sequencing of a genotype VIId Newcastle disease virus isolated from laying ducks in Jiangsu, China. Genome Announc 3:e01412-e01415

26. Duan Z, Ji X, Xu H, Zhao J, Ruan Y, Chen J (2015) Identification of a genotype VIld Newcastle disease virus isolated from sansui sheldrake ducks in Guizhou province, China. Genome Announc 3:e00161

27. Wang $X$, Gong Z, Zhao L, Wang J, Sun G, Liu Y, Tao P, Zhang H, Li S, Jiang F, Hu Y, Zhang X (2013) Complete genome sequences of Newcastle disease virus strains isolated from three different poultry species in China. Genome Announc 1:e00198

28. Zhang S, Zhao L, Wang X, Zhang D, Zhao J, Zhang G (2011) Serologic and virologic survey for evidence of infection with velogenic Newcastle disease virus in Chinese duck farms. Avian Dis 55:476-479 
29. Vidanovic D, Sekler M, Asanin R, Milic N, Nisavic J, Petrovic T, Savic V (2011) Characterization of velogenic Newcastle disease viruses isolated from dead wild birds in Serbia during 2007. J Wildl Dis 47:433-441

30. Liu H, Wang Z, Wu Y, Zheng D, Sun C, Bi D, Zuo Y, Xu T (2007) Molecular epidemiological analysis of Newcastle disease virus isolated in China in 2005. J Virol Methods 140:206-211

31. Liu H, Wang Z, Wang Y, Sun C, Zheng D, Wu Y (2008) Characterization of Newcastle disease virus isolated from waterfowl in China. Avian Dis 52:150-155

32. Tsai HJ, Chang KH, Tseng CH, Frost KM, Manvell RJ, Alexander DJ (2004) Antigenic and genotypical characterization of Newcastle disease viruses isolated in Taiwan between 1969 and 1996. Vet Microbiol 104:19-30

33. Barber MR, Aldridge JR Jr, Webster RG, Magor KE (2010) Association of RIG-I with innate immunity of ducks to influenza. Proc Natl Acad Sci U S A 107:5913-5918

34. Sun Y, Ding N, Ding SS, Yu S, Meng C, Chen H, Qiu X, Zhang S, Yu Y, Zhan Y, Ding C (2013) Goose RIG-I functions in innate immunity against Newcastle disease virus infections. Mol Immunol 53:321-327

35. Yoneyama M, Kikuchi M, Natsukawa T, Shinobu N, Imaizumi T, Miyagishi M, Taira K, Akira S, Fujita T (2004) The RNA helicase RIG-I has an essential function in double-stranded RNA-induced innate antiviral responses. Nat Immunol 5:730-737

36. Sick C, Schultz U, Munster U, Meier J, Kaspers B, Staeheli P (1998) Promoter structures and differential responses to viral and nonviral inducers of chicken type I interferon genes. J Biol Chem 273:9749-9754

37. Loo YM, Fornek J, Crochet N, Bajwa G, Perwitasari O, Martinez-Sobrido L, Akira S, Gill MA, Garcia-Sastre A, Katze MG, Gale M Jr (2008) Distinct RIG-I and MDA5 signaling by RNA viruses in innate immunity. J Virol 82:335-345

38. Bowie AG, Unterholzner L (2008) Viral evasion and subversion of pattern-recognition receptor signalling. Nat Rev Immunol 8:911-922

39. Sun Q, Sun L, Liu HH, Chen X, Seth RB, Forman J, Chen ZJ (2006) The specific and essential role of MAVS in antiviral innate immune responses. Immunity 24:633-642

40. Kumar H, Kawai T, Kato H, Sato S, Takahashi K, Coban C, Yamamoto M, Uematsu S, Ishii KJ, Takeuchi O, Akira S (2006) Essential role of IPS-1 in innate immune responses against RNA viruses. J Exp Med 203:1795-1803

41. Andrejeva J, Childs KS, Young DF, Carlos TS, Stock N, Goodbourn S, Randall RE (2004) The $V$ proteins of paramyxoviruses bind the IFN-inducible RNA helicase, mda-5, and inhibit its activation of the IFN-beta promoter. Proc Natl Acad Sci U S A 101:17264-17269

42. Anis Z, Morita T, Azuma K, Ito H, Ito T, Shimada A (2013) Histopathological alterations in immune organs of chickens and ducks after experimental infection with virulent 9a5b newcastle disease virus. J Comp Pathol 149:82-93

43. Wilden $H$, Fournier $P$, Zawatzky R, Schirrmacher V (2009) Expression of RIG-I, IRF3, IFN-beta and IRF7 determines resistance or susceptibility of cells to infection by Newcastle Disease Virus. Int J Oncol 34:971-982

44. Kang Y, Feng M, Zhao X, Dai X, Xiang B, Gao P, Li Y, Li Y, Ren T (2016) Newcastle disease virus infection in chicken embryonic fibroblasts but not duck embryonic fibroblasts is associated with elevated host innate immune response. Virol I 13:41

45. Yang C, Liu F, Chen S, Wang M, Jia R, Zhu D, Liu M, Sun K, Yang Q Wu Y, Chen X, Cheng A (2016) Identification of 2'-5'-oligoadenylate synthetase-like gene in goose: gene structure, expression patterns, and antiviral activity against Newcastle disease virus. J Interferon Cytokine Res 36:563-572

46. Dai Y, Cheng X, Liu M, Shen X, Li J, Yu S, Zou J, Ding C (2014) Experimental infection of duck origin virulent Newcastle disease virus strain in ducks. BMC Vet Res 10:164

47. Wang Y, Duan Z, Hu S, Kai Y, Wang X, Song Q, Zhong L, Sun Q, Wang X, Wu Y, Liu X (2012) Lack of detection of host associated differences in Newcastle disease viruses of genotype VIId isolated from chickens and geese. Virol J 9:197

48. Liu M, Wei Y, Dai Y, Cheng X, Zhou S, Pan Z, Xu L, Jiao X (2010) Isolation and preliminary identification of a virulent Newcastle disease virus isolate of duck origin. Chin J Anim Infect Dis 18:67-71

49. Zhong Z, Ji Y, Fu Y, Liu B, Zhu Q (2015) Molecular characterization and expression analysis of the duck viperin gene. Gene 570:100-107
50. Xu Q, Chen Y, Zhao W, Zhang T, Liu C, Qi T, Han Z, Shao Y, Ma D, Liu S (2016) Infection of goose with genotype VIld Newcastle disease virus of goose origin elicits strong immune responses at early stage. Front Microbiol 7:1587

51. Pantin-Jackwood MJ, Costa-Hurtado M, Miller PJ, Afonso CL, Spackman E, Kapczynski DR, Shepherd E, Smith D, Swayne DE (2015) Experimental co-infections of domestic ducks with a virulent Newcastle disease virus and low or highly pathogenic avian influenza viruses. Vet Microbiol 177:7-17

52. Njagi LW, Nyaga PN, Bebora LC, Mbuthia PG, Minga UM (2012) Effect of immunosuppression on newcastle disease virus persistence in ducks with different immune status. ISRN Vet Sci 2012:253809

53. Li ZJ, Li Y, Chang S, Ding Z, Mu LZ, Cong YL (2010) Antigenic variation between Newcastle disease viruses of goose and chicken origin. Arch Virol 155:499-505

54. Lee EK, Jeon WJ, Kwon JH, Yang CB, Choi KS (2009) Molecular epidemiological investigation of Newcastle disease virus from domestic ducks in Korea. Vet Microbiol 134:241-248

55. Otim Onapa M, Christensen H, Mukiibi GM, Bisgaard M (2006) A preliminary study of the role of ducks in the transmission of Newcastle disease virus to in-contact rural free-range chickens. Trop Anim Health Prod 38:285-289

56. Bouzari M (2014) The response of ducks to V4 Newcastle disease virus and its transmission to contact ducks and domestic chickens. Vet Res Forum 5:145-148

57. Fuller C, Londt B, Dimitrov KM, Lewis N, van Boheemen $S$, Fouchier $R$, Coven F, Goujgoulova G, Haddas R, Brown I (2017) An epizootiological report of the re-emergence and spread of a lineage of virulent Newcastle disease virus into Eastern Europe. Transbound Emerg Dis 64:1001-1007

58. Dortmans JC, Rottier PJ, Koch G, Peeters BP (2011) Passaging of a Newcastle disease virus pigeon variant in chickens results in selection of viruses with mutations in the polymerase complex enhancing virus replication and virulence. J Gen Virol 92:336-345

59. Alexander DJ, Campbell G, Manvell RJ, Collins MS, Parsons G, McNulty MS (1992) Characterisation of an antigenically unusual virus responsible for two outbreaks of Newcastle disease in the Republic of Ireland in 1990. Vet Rec 130:65-68

60. Kim LM, King DJ, Curry PE, Suarez DL, Swayne DE, Stallknecht DE, Slemons RD, Pedersen JC, Senne DA, Winker K, Afonso CL (2007) Phylogenetic diversity among low-virulence newcastle disease viruses from waterfowl and shorebirds and comparison of genotype distributions to those of poultry-origin isolates. J Virol 81:12641-12653

61. Liu H, Zhao Y, Zheng D, Lv Y, Zhang W, Xu T, Li J, Wang Z (2011) Multiplex RT-PCR for rapid detection and differentiation of class I and class II Newcastle disease viruses. J Virol Methods 171:149-155

62. Hines NL, Miller CL (2012) Avian paramyxovirus serotype-1: a review of disease distribution, clinical symptoms, and laboratory diagnostics. Vet Med Int 2012:708216

63. Zhu J, Xu H, Liu J, Zhao Z, Hu S, Wang X, Liu X (2014) Surveillance of avirulent Newcastle disease viruses at live bird markets in eastern China during 2008-2012 reveals a new sub-genotype of class I virus. Virol J $11: 211$

64. Brown VR, Bevins SN (2017) A review of virulent Newcastle disease viruses in the United States and the role of wild birds in viral persistence and spread. Vet Res 48:68

65. Umali DV, Ito H, Shirota K, Katoh H, Ito T (2014) Characterization of complete genome sequence of genotype VI and VII velogenic Newcastle disease virus from Japan. Virus Genes 49:89-99

66. Meng C, Rehman ZU, Liu K, Qiu X, Tan L, Sun Y, Liao Y, Song C, Yu S, Ding Z, Nair V, Munir M, Ding C (2018) Potential of genotype VII Newcastle diseaseviruses to cause differential infections in chickens and ducks. Transbound Emerg Dis, in press https://doi.org/10.1111/tbed.12965

67. Huang Y, Yang S, Hu B, Xu C, Gao D, Zhu M, Huang Q, Zhang L, Wu J, Zhang X, Khan MI (2015) Genetic, pathogenic and antigenic diversity of Newcastle disease viruses in Shandong Province, China. Vet Microbiol 180:237-244

68. Fan S, Wang T, Gao X, Ying Y, Li X, Li Y, Li Y, Ma J, Sun H, Chu D, Xu Y, Yang S, Li Q, Gao Y, Xia X (2015) Phylogenetic analysis of Newcastle disease viruses isolated from wild birds in the Poyang Lake region of China. J Vet Med Sci 77:1143-1149 
69. Wille M, Avril A, Tolf C, Schager A, Larsson S, Borg O, Olsen B, Waldenstrom $J$ (2015) Temporal dynamics, diversity, and interplay in three components of the virodiversity of a Mallard population: influenza A virus, avian paramyxovirus and avian coronavirus. Infect Genet Evol 29:129-137

70. Miller PJ, Estevez C, Yu Q, Suarez DL, King DJ (2009) Comparison of viral shedding following vaccination with inactivated and live Newcastle disease vaccines formulated with wild-type and recombinant viruses. Avian Dis 53:39-49

71. Miller PJ, Kim LM, Ip HS, Afonso CL (2009) Evolutionary dynamics of Newcastle disease virus. Virology 391:64-72

72. Read AF, Baigent SJ, Powers C, Kgosana LB, Blackwell L, Smith LP, Kennedy DA, Walkden-Brown SW, Nair VK (2015) Imperfect vaccination can enhance the transmission of highly virulent pathogens. PLoS Biol 13:e1002198

73. Miller PJ, Decanini EL, Afonso CL (2010) Newcastle disease: evolution of genotypes and the related diagnostic challenges. Infect Genet Evol 10:26-35

74. Hu S, Ma H, Wu Y, Liu W, Wang X, Liu Y, Liu X (2009) A vaccine candidate of attenuated genotype VII Newcastle disease virus generated by reverse genetics. Vaccine 27:904-910

75. Mase M, Inoue T, Imada T (2009) Genotyping of Newcastle disease viruses isolated from 2001 to 2007 in Japan. J Vet Med Sci 71:1101-1104

76. Hu B, Huang Y, He Y, Xu C, Lu X, Zhang W, Meng B, Yan S, Zhang X (2010) Avian influenza virus and Newcastle disease virus (NDV) surveillance in commercial breeding farm in China and the characterization of Class I NDV isolates. Vet Microbiol 144:82-86

77. Lindh E, Ek-Kommonen C, Vaananen VM, Alasaari J, Vaheri A, Vapalaht O, Huovilainen A (2012) Molecular epidemiology of outbreak-associated and wild-waterfowl-derived newcastle disease virus strains in Finland, including a novel class I genotype. J Clin Microbiol 50:3664-3673

78. Wang J, Lv Y, Zhang Y, Zheng D, Zhao Y, Castellan D, Liu H, Wang Z (2016) Genomic characterizations of a Newcastle disease virus isolated from ducks in live bird markets in China. PLoS One 11:e0158771

79. Hu Y, Duan Z, Ji X, Zhao J, Xu H, Hu S, Liu X (2016) Complete genome sequences of two subgenotype $1 \mathrm{~b}$ Newcastle disease viruses isolated from Sansui sheldrake Ducks in Guizhou, China. Genome Announc 4:e01347

80. Kistler WM, Gibbs SE, Stallknecht DE, Yabsley MJ (2015) Wood ducks (Aix sponsa) as potential reservoirs for avian influenza and avian paramyxoviruses. Avian Pathol 44:169-174

81. Liu H, Chen F, Zhao Y, Zheng D, Li J, Xu T, Qi L, Wang Z (2010) Genomic characterization of the first class I Newcastle disease virus isolated from the mainland of China. Virus Genes 40:365-371

82. Liu X, Wang X, Wu S, Hu S, Peng Y, Xue F, Liu X (2009) Surveillance for avirulent Newcastle disease viruses in domestic ducks (Anas platyrhynchos and (airina moschata) at live bird markets in Eastern China and characterization of the viruses isolated. Avian Pathol 38:377-391

83. Meng C, Qiu X, Jin S, Yu S, Chen H, Ding C (2012) Whole genome sequencing and biological characterization of Duck/JS/10, a new lentogenic class I Newcastle disease virus. Arch Virol 157:869-880

84. Gaikwad S, Kim JY, Lee HJ, Jung SC, Choi KS (2016) Genetic characterization and evolutionary analysis of Newcastle disease virus isolated from domestic duck in South Korea. Gene 579:34-40

85. Yurchenko KS, Sobolev IA, Glushchenko AV, Shestopalov AM (2015) Complete genome sequence of genotype IB Newcastle disease virus isolated from a mallard (Anas platyrhynchos) in Russia. Genome Announc 3:e01414-e01415

86. Tolf C, Wille M, Haidar AK, Avril A, Zohari S, Waldenstrom J (2013) Prevalence of avian paramyxovirus type 1 in Mallards during autumn migration in the western Baltic Sea region. Virol J 10:285

87. Snoeck CJ, Marinelli M, Charpentier E, Sausy A, Conzemius T, Losch S, Muller CP (2013) Characterization of newcastle disease viruses in wild and domestic birds in Luxembourg from 2006 to 2008. Appl Environ Microbiol 79:639-645

88. Snoeck CJ, Adeyanju AT, Owoade AA, Couacy-Hymann E, Alkali BR, Ottosson U, Muller CP (2013) Genetic diversity of newcastle disease virus in wild birds and pigeons in West Africa. Appl Environ Microbiol 79:7867-7874

89. Kim BY, Lee DH, Kim MS, Jang JH, Lee YN, Park JK, Yuk SS, Lee JB, Park SY, Choi IS, Song CS (2012) Exchange of Newcastle disease viruses in Korea: the relatedness of isolates between wild birds, live bird markets, poultry farms and neighboring countries. Infect Genet Evol 12:478-482
90. Hoque MA, Burgess GW, Karo-Karo D, Cheam AL, Skerratt LF (2012) Monitoring of wild birds for Newcastle disease virus in north Queensland, Australia. Prev Vet Med 103:49-62

91. Choi KS, Lee EK, Jeon WJ, Kwon JH, Lee JH, Sung HW (2012) Molecular epidemiologic investigation of lentogenic Newcastle disease virus from domestic birds at live bird markets in Korea. Avian Dis 56:218-223

92. Shim JB, So HH, Won HK, Mo IP (2011) Characterization of avian paramyxovirus type 1 from migratory wild birds in chickens. Avian Pathol 40:565-572

93. Ruenphet S, Jahangir A, Shoham D, Morikawa K, Miyoshi Y, Hanawa E, Okamura M, Nakamura M, Takehara K (2011) Surveillance and characterization of Newcastle disease viruses isolated from northern pintail (Anas acuta) in Japan during 2006-09. Avian Dis 55:230-235

94. Cai S, Li J, Wong MT, Jiao P, Fan H, Liu D, Liao M, Jiang J, Shi M, Lam TT, Ren T, Leung FC (2011) Genetic characterization and evolutionary analysis of 4 Newcastle disease virus isolate full genomes from waterbirds in South China during 2003-2007. Vet Microbiol 152:46-54

95. Jindal N, Chander Y, Chockalingam AK, de Abin M, Redig PT, Goyal SM (2009) Phylogenetic analysis of Newcastle disease viruses isolated from waterfowl in the upper midwest region of the United States. Virol J 6:191

96. Lindh E, Huovilainen A, Ratti O, Ek-Kommonen C, Sironen T, Huhtamo E, Poysa H, Vaheri A, Vapalahti O (2008) Orthomyxo-, paramyxo- and flavivirus infections in wild waterfowl in Finland. Virol J 5:35

97. Sakai K, Sakabe G, Tani O, Watanabe Y, Jahangir A, Nakamura M, Takehara K (2007) Characterization of Newcastle disease virus isolated from northern pintail (Anas acuta) in Japan. J Vet Med Sci 69:1307-1311

98. Wajid A, Dundon WG, Hussain T, Babar ME (2018) Pathotyping and genetic characterization of avian avulavirus-1 from domestic and wild waterfowl, geese and black swans in Pakistan, 2014 to 2017. Arch Virol 163:2513-2518

99. Kabilov MR, Alikina TY, Yurchenko KS, Glushchenko AV, Gunbin KV, Shestopalov AM, Gubanova NV (2016) Complete genome sequences of two Newcastle disease virus strains isolated from a wild duck and a pigeon in Russia. Genome Announc 4:e01348

100. Wajid A, Rehmani SF, Wasim M, Basharat A, Bibi T, Arif S, Dimitrov KM, Afonso CL (2016) Complete genome sequence of a virulent Newcastle disease virus strain isolated from a clinically healthy duck (Anas platyrhynchos domesticus) in Pakistan. Genome Announc 4:e00730

101. Habib M, Yaqub T, Nazir J, Shehzad W, Aziz UI R, Sohail T, Mukhtar N, Mehboob A, Munir M, Shabbir MZ (2018) Genomic and biological characterization of Newcastle disease viruses isolated from migratory mallards (Anas platyrhynchos). Arch Virol 163:2179-2188

102. Xie Z, Xie L, Xu Z, Liu J, Pang Y, Deng X, Xie Z, Fan Q, Luo S (2013) Identification of a genotype IX Newcastle disease virus in a Guangxi white duck. Genome Announc 1:e00836

103. Takakuwa H, Ito T, Takada A, Okazaki K, Kida H (1998) Potentially virulent Newcastle disease viruses are maintained in migratory waterfowl populations. Jpn J Vet Res 45:207-215

104. Qin ZM, Tan LT, Xu HY, Ma BC, Wang YL, Yuan XY, Liu WJ (2008) Pathotypical characterization and molecular epidemiology of Newcastle disease virus isolates from different hosts in China from 1996 to 2005. J Clin Microbiol 46:601-611

105. Xu Q, Sun J, Gao M, Zhao S, Liu H, Zhang T, Han Z, Kong X, Liu S (2017) Genetic, antigenic, and pathogenic characteristics of Newcastle disease viruses isolated from geese in China. J Vet Diagn Invest 29:489-498

106. Yao CF, Liu WB, Hu SL, Ma HL, Xue F, Liu HM, Liu XF (2009) Biological characteristics and sequence analysis of fusion genes of Newcastle disease virus isolates. Bing Du Xue Bao 25:117-124

107. Chen XQ, Li ZB, Hu GX, Gu SZ, Zhang S, Ying Y, Gao FS (2015) Isolation, identification, and sequencing of a goose-derived Newcastle disease virus and determination of its pathogenicity. Avian Dis 59:235-243

108. Xu M, Chang S, Ding Z, Gao HW, Wan JY, Liu WS, Liu LN, Gao Y, Xu J (2008) Genomic analysis of Newcastle disease virus strain NA-1 isolated from geese in China. Arch Virol 153:1281-1289

109. Wu S, Wang W, Yao C, Wang X, Hu S, Cao J, Wu Y, Liu W, Liu X (2011) Genetic diversity of Newcastle disease viruses isolated from domestic poultry species in Eastern China during 2005-2008. Arch Virol 156:253-261

110. Liu H, Lv Y, Afonso CL, Ge S, Zheng D, Zhao Y, Wang Z (2013) Complete genome sequences of new emerging Newcastle disease virus strains isolated from china. Genome Announc 1:e00129 